\title{
Synthesis, Variable Temperature NMR Investigations and Solid State Characterization of Novel Octafluorofluorene Compounds *
}

\author{
Fabio Marchetti, ${ }^{\S, a}$ Fabio Marchetti, ${ }^{\dagger, a}$ Francesco Masi, ${ }^{b}$ Guido Pampaloni, ${ }^{a, *}$ \\ Vincenzo Passarelli, ${ }^{a, c}$ Anna Sommazzi, ${ }^{d}$ Silvia Spera ${ }^{d}$
}

Keywords: fluorine, fluoro derivatives, octafluorofluorene, crystal structures, NMR spectra

The preparation of a number of new 9-substituted octafluorofluorene derivatives, solution NMR studies, and the first examples of solid state structures of octafluorofluorenes $\left[1,2,3,4,5,6,7,8\right.$-octafluorofluorene, $\mathrm{C}_{13} \mathrm{H}_{2} \mathrm{~F}_{8}, \quad \mathbf{1} ; 1,2,3,4,5,6,7,8-$ octafluoro-9-(pentafluoro)phenylfluorene, $\quad \mathrm{C}_{19} \mathrm{HF}_{13}$, $\mathrm{C}_{19} \mathrm{HF}_{13}$, $1,1^{\prime}, 2,2^{\prime}, 3,3^{\prime}, 4,4^{\prime}, 5,5^{\prime}, 6,6^{\prime}, 7,7^{\prime}, 8,8^{\prime}$-hexadecafluoro-9,9'-bifluorenyl,
$\mathrm{C}_{26} \mathrm{H}_{2} \mathrm{~F}_{16}, \mathbf{1 1}$ ] are reported. Variable-temperature ${ }^{19} \mathrm{~F}-\mathrm{NMR}$ investigations have been performed on the 9-aryl substituted compounds $\quad 1,2,3,4,5,6,7,8$-octafluoro-9-(pentafluoro)phenyl-9hydroxyfluorene, $\quad \mathrm{C}_{19} \mathrm{HF}_{13} \mathrm{O}, \quad \mathbf{4}, \quad 1,2,3,4,5,6,7,8$-octafluoro-9(nonafluoro-4'-biphenylyl)-9-hydroxyfluorene, $\mathrm{C}_{25} \mathrm{HF}_{17} \mathrm{O}, \mathbf{5}$, and $\mathbf{8}$,

\section{Introduction}

The fluorination of aryl groups determines important effects in reactivity. ${ }^{1}$ ] More specifically, fluoro- and polyfluoro-aryl substituents can induce stabilizing effects on carbanions, when compared with the analogous all-hydrogen systems. ${ }^{[2]}$ This stabilization has been observed in tetraarylborate ions: for instance, at variance with the tetraphenylborate $\left[\mathrm{B}\left(\mathrm{C}_{6} \mathrm{H}_{5}\right)_{4}\right]^{-}$, which is thermally unstable and decomposes under acidic and oxidant conditions, $\left.{ }^{[}{ }_{3}\right]$ the 3,5-fluoroalkyl-substituted anions $\left[\mathrm{B}\left[\mathrm{C}_{6} \mathrm{H}_{3}\left(\mathrm{R}_{\mathrm{f}}\right)_{2}\right]_{4}\right]^{-}\left[\mathrm{R}_{\mathrm{f}}=\mathrm{CF}_{3},\left(\mathrm{CF}_{2}\right)_{3} \mathrm{CF}_{3}, \mathrm{CF}\left(\mathrm{CF}_{3}\right)_{2}\right]$ are thermally stable and resist highly acidic conditions. ${ }^{[4]}$ Relevantly, when used in olefin polymerization, the salts of these fluorine-rich anions are better co-catalysts than the non-fluorinated ones. ${ }^{[5]}$

Fluoro-substituted fluorene derivatives have been known since long time ${ }^{[6]}$ and some of these compounds have attracted interest for their biological properties [7] or for their possible use as standards in environmental analyses. ${ }^{[8]}$

[a] Dipartimento di Chimica e Chimica Industriale, Università di Pisa, Via Risorgimento 35, I-56126 Pisa, Italy Fax: +0502219246

E-mail:pampa@dcci.unipi.it

[b] Polimeri Europa, Piazza Boldrini 1, I-20097 San Donato Milanese, Italy

[c] Present Address:CSIC-ICMA Facultad de Ciencias, C/ Pedro Cerbuna 12, E-50009 Zaragoza, Spain.

[d] Eni S.p.A., Centro Ricerche per le Energie non Convenzionali Istituto Eni Donegani, via G. Fauser 4, I-28100 Novara, Italy In memoriam Roberto Santi (1948 - 2003).

Born in Bologna (Italy) in 1974

Born in Castelfiorentino (FI, Italy) in 1950.

Supporting information for this article is available on the WWW under http://www.eurjoc.org/ or from the author and the energetic barriers to rotation of the aryl have been determined. A lower rotational barrier is observed for compound 4 with respect to compound $\mathbf{8}$, while $\mathbf{5}$ does not show fluxional behaviour below $338 \mathrm{~K}$. The results of the variable-temperature experiments performed on $\mathbf{8}$ have been rationalized by 2D NMR studies, and compared to the solid state data resulting from the Xray structural analysis.

(C) WILEY-VCH Verlag GmbH \& Co. KGaA, 69451 Weinheim, Germany, 2007)

Within the series of fluoro-substituted fluorenes, a limited number of octafluorofluorene species has been reported. ${ }^{[1,2,9]}$ Some of us have recently described the catalytic properties of octafluorofluorenyl anions, ${ }^{[10]}$ which made us keen on the preparation of new octafluorofluorene compounds. The synthetic procedures are reported herein, together with the spectroscopic characterization ( ${ }^{1} \mathrm{H}$ and ${ }^{19} \mathrm{~F}$ NMR), and some $\mathrm{X}$ ray molecular determinations; furthermore, variable temperature ${ }^{19} \mathrm{~F} \quad \mathrm{NMR}$ experiments will be discussed.

\section{Results and Discussion}

1. Synthesis

Some of the octafluorofluorene derivatives discussed in this paper $\quad\left[1,2,3,4,5,6,7,8-\right.$ octafluorofluorene, $\quad \mathrm{C}_{13} \mathrm{H}_{2} \mathrm{~F}_{8}, \quad \mathbf{1}$; 1,2,3,4,5,6,7,8-octafluoro-9-(pentafluoro)phenylfluorene, $\mathrm{C}_{19} \mathrm{HF}_{13}$, 8; 1,2,3,4,5,6,7,8-octafluoro-9-hydroxyfluorene, $\mathrm{C}_{13} \mathrm{H}_{2} \mathrm{~F}_{8} \mathrm{O}$, 9] have been prepared according to the literature $;{ }^{[2,9]}$ new high-yield synthetic procedures have been developed for the derivatives 27,10-11 (see schemes 2, 3). Compounds 2-5 (9-aryl substituted octafluoro-9-hydroxyfluorenes) have been obtained by reaction of octafluorofluorenone with one equivalent of $\operatorname{LiAr}[\mathrm{Ar}=2,4-$ bis(trifluoromethyl)phenyl, 3,5-bis(trifluoromethyl)phenyl, (pentafluoro)phenyl, (nonafluoro)-4-biphenylyl], in diethyl ether at temperatures in the range between -70 and $-20^{\circ} \mathrm{C}$, see Scheme 1 . 


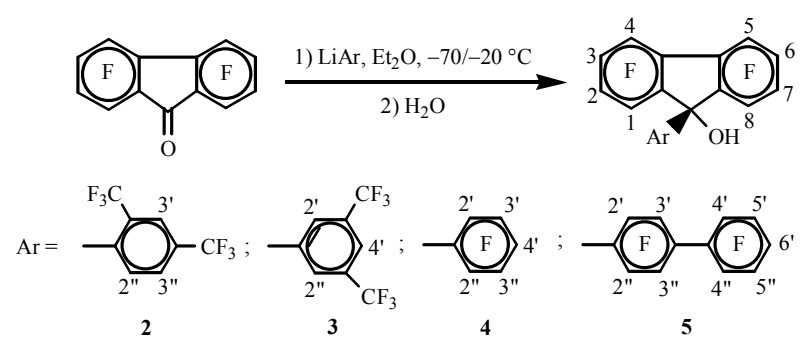

Scheme 1: Preparation of compounds 2-5.

The octafluorofluorenes 6-8 have been synthesized respectively from the hydroxy-derivatives $\mathbf{2 - 4}$ by bromination with $\mathrm{PBr}_{3}$, followed by zinc reduction in acetic acid at room temperature, see Scheme 2.

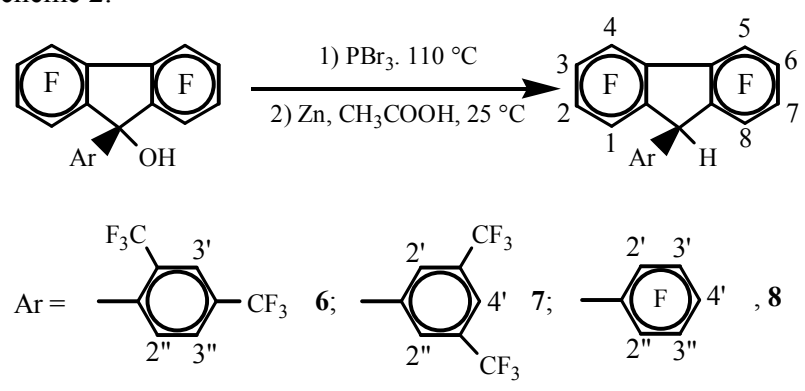

Scheme 2: Preparation of compounds 6-8.

The dimer $\mathbf{1 1}$ has been prepared from 1,2,3,4,5,6,7,8octafluorofluorenone by the sequence of reactions illustrated in Scheme 3.
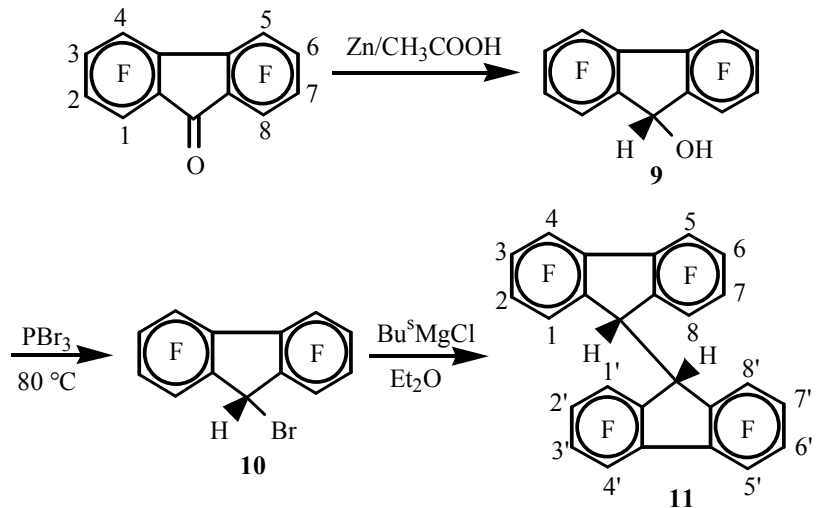

Scheme 3: Preparation of compounds 9-11.

All compounds 2-11 are colourless crystalline materials, and have been characterized by ${ }^{1} \mathrm{H}-$ and ${ }^{19} \mathrm{~F}-\mathrm{NMR}$ spectroscopy. Moreover, the solid state molecular structures of 1, $\mathbf{8}$ and $\mathbf{1 1}$ have been ascertained by X-ray diffraction analyses.

\section{NMR studies}

The ${ }^{1} \mathrm{H}$ NMR spectra of compounds 6-11 (in $\mathrm{CDCl}_{3}$ ) show the presence of a relatively low-field resonance due to the $\mathrm{C}\left(s p^{3}\right)-H$ proton, falling in the range $5.40(\mathbf{1 1}) \div 6.16$ (9) $\mathrm{ppm}$, as consequence of the electron withdrawing action of the octafluorofluorenyl frame. Otherwise, the ${ }^{1} \mathrm{H}$ NMR spectra $\left(\mathrm{CDCl}_{3}\right)$ of 2-5, 9 exhibit the peak assigned to the $\mathrm{OH}$ proton in the range $2.62(9) \div 3.75(4)$ ppm.

In the ${ }^{19} \mathrm{~F}$ NMR spectra, the fluorine atoms belonging to the fluorenyl unit resonate respectively at $c a$. $-130 \mathrm{ppm}$ (F1, F8), -140 ppm (F4, F5), -150 ppm (F2, F7, F3, F6).

We noticed that the ${ }^{19} \mathrm{~F}-\mathrm{NMR}$ spectrum of $\mathbf{8}$ in THF- $\mathrm{d}^{8}$ appeared markedly different from that reported by Vlasov (recorded in $\left.\mathrm{CCl}_{4}\right),{ }^{[9 \mathrm{a}]}$ then we decided to deepen this point. The solution structure of 8 has been elucidated by means of 1D and 2D ${ }^{19} \mathrm{~F}$-NMR experiments: at $298 \mathrm{~K}$, the monodimensional spectrum in THF- $\mathrm{d}^{8}$ shows four resonances for the fluorenyl moiety, indicating that the two $\mathrm{C}_{6}$-rings should be equivalent. On the other hand, the presence of five signals for the $\mathrm{C}_{6} \mathrm{~F}_{5}$ group suggests that both the ortho- and the meta- positions on the (pentafluoro)phenyl ring are non-equivalent. The ${ }^{19} \mathrm{~F},{ }^{19} \mathrm{~F}-\mathrm{COSY}$ and NOESY spectra have led to the assignments reported in Table 1.

Table 1. ${ }^{19} \mathrm{~F}-\mathrm{NMR}$ resonances of $\mathbf{8}$ in various solvents.

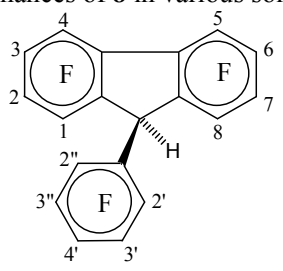

\begin{tabular}{lllll}
\hline & $\mathrm{CCl}_{4}{ }^{\mathrm{a}}$ & $\mathrm{C}_{6} \mathrm{D}_{6}$ & $\mathrm{THF}$ & $\mathrm{CDCl}_{3}$ \\
\hline 1,8 & -143.3 & -144.3 & -131.3 & -133.8 \\
2,7 & -153.9 & -152.6 & -150.4 & -152.1 \\
3,6 & -153.9 & -153.7 & -150.8 & -152.4 \\
4,5 & -134.7 & -134.4 & -140.0 & -143.1 \\
$2^{\prime}\left(2^{\prime \prime}\right)$ & -142.1 & -142.6 & -139.0 & -142.6 \\
$2^{\prime \prime}$ & -- & -143.6 & -138.5 & -141.6 \\
3'(3") & -161.5 & -160.7 & -158.3 & -160.7 \\
$3^{\prime \prime}$ & -- & -- & -157.9 & -160.1 \\
4, & -153.9 & -152.0 & -150.5 & -152.4 \\
\hline
\end{tabular}

${ }^{\mathrm{a}} \delta$-values referred to $\mathrm{CFCl}_{3}$, recalculated from ref [9a].

Interestingly the ${ }^{19} \mathrm{~F},{ }^{19} \mathrm{~F}-\mathrm{NOESY}$ spectrum of $\mathbf{8}$ only shows correlation between the fluorines $\mathrm{F} 1 / \mathrm{F} 8$ and $\mathrm{F} 2$ ', while no crosspeak is observed between F1/F8 and F2". According to this, the orientation of the pentafluoropheyl with respect to the fluorenyl moiety should be non-symmetric, making both the ortho- and $m e t a-$ positions at the aryl ring non-equivalent. However, exchange cross-peaks have been observed both between F2' (-139.0 ppm) and F2" (-138.5 ppm), and between F3' (-158.3 ppm) and F3" $(-157.9 \mathrm{ppm})$ : these features suggest that, although the aryl rotation is slow at room temperature, it is not completely inhibited.

Hence, a variable temperature ${ }^{19} \mathrm{~F}-\mathrm{NMR}$ study was carried out on compound 8 in THF- $\mathrm{d}^{8}$ (see figure 1) and, for comparison, in $\mathrm{CDCl}_{3}$, too. As a general remark, the hindered rotation of the aryl ring is observable both in THF-d $\mathrm{d}^{8}$ and in $\mathrm{CDCl}_{3}$. Nevertheless, the coalescences of the resonances due to the non-equivalent $\mathrm{F} 2$ ' and $\mathrm{F}^{\prime \prime}$, and F3' and F3", respectively, have been seen at different temperatures on varying the solvent (see Table 2).

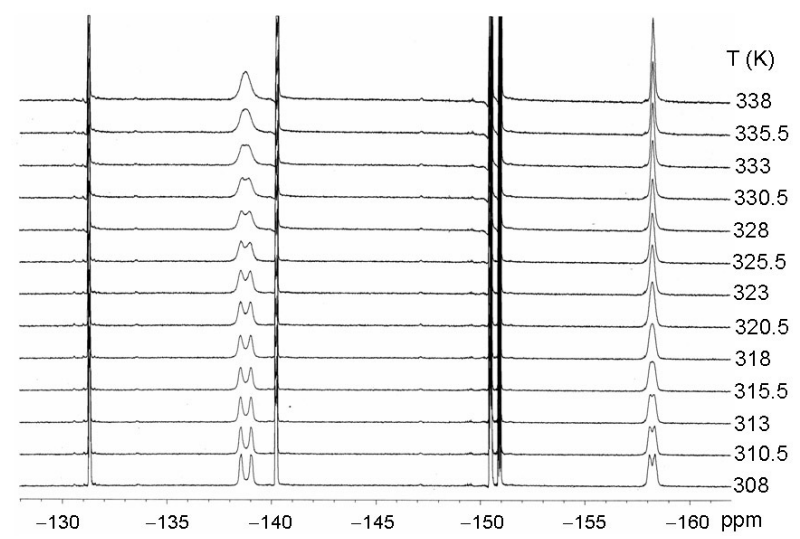

Figure 1. Variable Temperature ${ }^{19} \mathrm{~F}-\mathrm{NMR}$ study on compound $\mathbf{8}$ (solvent THF-d ${ }^{8}$.

The rate constants, $k_{c}$, and the activation free energy, $\Delta G^{\#}$, for the $\mathrm{C}_{6} \mathrm{~F}_{5}$ ring rotation, have been calculated according to the equations: $\mathrm{k}_{\mathrm{c}}=\pi \frac{\Delta \delta}{\sqrt{2}}(\Delta \delta$ is the difference between the chemical shifts of the two resonances related to either the $o$ fluorines or the $m$-fluorines respectively) 
and $\Delta G^{\#}=4.57 T_{c}\left(10.32+\ln \frac{T_{c}}{k_{c}}\right)$, where $T_{c}$ is the coalescence temperature $(\mathrm{K})$, see Table $2 .^{[11]}$

Table 2. Spectral, kinetic and activation parameters related to the rotation of the pentafluorophenyl ring in compounds $\mathbf{4}$ and $\mathbf{8}$.

\begin{tabular}{|c|c|c|c|c|c|c|c|}
\hline & \multicolumn{2}{|c|}{$\begin{array}{l}\Delta \delta \\
(\mathrm{Hz})\end{array}$} & \multicolumn{2}{|l|}{$\begin{array}{c}k_{c} \\
\left(\mathrm{~s}^{-1}\right)\end{array}$} & \multicolumn{2}{|c|}{$\begin{array}{c}T_{c} \\
(\mathrm{~K})\end{array}$} & \multirow{2}{*}{$\begin{array}{c}\Delta G^{\#} \\
\left(\mathrm{kcal} \mathrm{mole}^{-1}\right)\end{array}$} \\
\hline & F2'/F2" & F3'/F3" & F2'/F2" & F3'/F3" & $\mathrm{F} 2^{\prime} / \mathrm{F} 2^{\prime \prime}$ & F3'/F3" & \\
\hline 4 & $78+3$ & $567+4$ & $175+7$ & $\begin{array}{l}\text { THF-d }^{8} \\
1259+9\end{array}$ & 222 & 245 & $102+05$ \\
\hline 8 & $134 \pm 3$ & $71 \pm 6$ & $310 \pm 22$ & $158 \pm 13$ & 333 & 316 & $15.8 \pm 0.1$ \\
\hline & $1881+3$ & $242+4$ & $4176+7$ & $\begin{array}{l}\mathrm{CDCl}_{3} \\
537 \pm 9\end{array}$ & 265 & 245 & $9.9 \pm 0.7$ \\
\hline 8 & $310 \pm 3$ & $132 \pm 3$ & $688 \pm 7$ & $293 \pm 7$ & 343 & 329 & $15.4 \pm 0.3$ \\
\hline
\end{tabular}

In contrast with the static ${ }^{19} \mathrm{~F}$ NMR spectrum shown by 8 at room temperature, compound $\mathbf{4}$, which differs from $\mathbf{8}$ for the presence of the hydroxy-substituent (see schemes 1,2), exhibits only one narrow doublet for the fluorine nuclei F2' and F2" (the multiplicity is consequence of the coupling with $\left.F 3^{\prime} / \mathrm{F} 3^{\prime \prime}\right)$ and one multiplet for the fluorines F3' and F3" (due to the couplings with F2'/F2" and F4'), in THF-d ${ }^{8}$ at room temperature. These features indicate that the rotation of the pentafluorophenyl substituent in $\mathbf{4}$ occurs rapidly on the NMR timescale already at room temperature. As the temperature is lowered, the doublet observed at room temperature for $\mathrm{F}^{\prime} / \mathrm{F} 2^{\prime \prime}$ gradually broadens and splits into a pair of doublets below $222 \mathrm{~K}\left(T_{C F 2}\right)$. Analogously, the F3'/F3" resonance, which appears as a multiplet at room temperature, splits into two false-triplets below $245 \mathrm{~K}$. A similar behaviour has been observed in $\mathrm{CDCl}_{3}$ (see Table 2 for $\mathrm{T}_{\mathrm{c}}$ ). The activation parameters calculated from these observations for compound $\mathbf{4}$ are reported in Table 2; the chemical shift separation in the absence of exchange has been estimated on the lowest temperature $(208 \mathrm{~K})$ spectra $\left(\mathrm{THF}-\mathrm{d}_{8}: 0.28\right.$ ppm for $\mathrm{F}^{\prime} / \mathrm{F}^{\prime \prime}$ and $2.01 \mathrm{ppm}$ for $\mathrm{F}^{\prime} / \mathrm{F}^{\prime \prime} ; \mathrm{CDCl}_{3}: 0.30 \mathrm{ppm}$ for $\mathrm{F}^{\prime} / \mathrm{F}^{\prime \prime}$ and $2.01 \mathrm{ppm}$ for $\left.\mathrm{F}^{\prime} / \mathrm{F}^{\prime \prime}\right)$. It is noteworthy that the $o$ fluorines within the aryl substituent $\left(F 2^{\prime}, F 2^{\prime \prime}\right)$ resonate at significantly different chemical shifts, in compound 4 (-135.9 $\mathrm{ppm})$ with respect to $8(-138.5,-139.0 \mathrm{ppm})$, at $298 \mathrm{~K}$ in THF-d ${ }^{8}$. This discrepancy might be the effect, in $\mathbf{4}$, of a hydrogen-bond involving the adjacent hydroxyl group. However, the possible interaction $\mathrm{F}-\mathrm{-H}-\mathrm{O}$ is evidently not strong enough to prevent the fast rotation of the aryl ring at room temperature.

The ${ }^{19} \mathrm{~F}$ NMR spectrum of compound 5 (in THF- $\mathrm{d}^{8}$ ) exhibits three pairs of distinct resonances for the fluorines F2' and F2", F3' and F3", F4' and F4", respectively (see Scheme 1). Such resonances have been seen at -131.9 and $-132.7 \mathrm{ppm},-148.9$ and $-150.7 \mathrm{ppm},-134.2$ and $-134.4 \mathrm{ppm}$, in the order given. On increasing the temperature up to $338 \mathrm{~K}$ (the highest temperature we could reach in $T H F-d^{8}$ ), the spectrum remains substantially unchanged, suggesting that the rotational barrier around the $\mathrm{C}\left(s p^{3}\right)$ Ar bond is much higher for compound 5 than for $\mathbf{4}$ and $\mathbf{8}$. This result appears to be an effect of the higher moment of inertia of the nonafluorobiphenylyl substituent, compared with that of the pentafluorophenyl substituent, see Schemes 1 and 2. According to that, the energy needed to overcome the rotational barrier increases significantly on passing from 4,8 to 5 , with consequent rise of the coalescence temperature.

The higher rotational barrier of the $-\mathrm{C}_{6} \mathrm{~F}_{5}$ unit observed in 8 with respect to $\mathbf{4}$ (see Table 2) is coherent with previous results found for 9 -substituted-9-arylfluorenes. ${ }^{[9]}$ In agreement with these reports, the activation free energy for the rotation of the aryl would depend on the encumbrance of the $\mathrm{R}$ substituent $(\mathrm{R}=\mathrm{H}, \mathrm{OH})$ : the larger $\mathrm{R}$ is, the higher is the energetic level of the ground state, and the smaller is the energy difference between the ground state and the transition one.

In addition, the observed little barriers $(10-15 \mathrm{kcal} / \mathrm{mol})$ and the negligible influence of the solvent (THF- $\left.\mathrm{d}_{8} v s . \mathrm{CDCl}_{3}\right)$ suggest that the aryl rotation takes place via a non-dissociative mechanism, ruling out the dissociative mechanistic proposal formulated by Chandross and Sheley for related substituted fluorenes. ${ }^{[12]}$

\section{X-ray structural studies of 1,8 , and 11 .}

A search on the Cambridge Crystallographic Data Centre ${ }^{[13]}$ revealed the absence of crystallographically characterized octafluoro-substituted fluorenes. This fact prompted us to investigate the X-ray molecular structure of some of the compounds reported in the previous section, with particular regard to $\mathbf{8}$ (we were eager to see whether the features evidenced in solution by ${ }^{19} \mathrm{~F}-\mathrm{NMR}$ spectroscopy found correspondence in the solid state or not)

Crystals suitable for $\mathrm{X}$ ray analyses were collected by slow evaporation of the solvents from toluene (compounds 8 and 11) or $\mathrm{C}_{6} \mathrm{D}_{6}$ (compound $\mathbf{1}$ ) solutions. The species $\mathbf{1}$ and $\mathbf{8}$ crystallize in the monoclinic space group $C 2 / c$. Figures 2 and 3 show the molecular structures and the crystal packing of the two compounds. Bond distances and angles for $\mathbf{1}$ and $\mathbf{8}$ are given as Supporting Information

\section{Figures 2 and 3 about here}

Figure 2. View of the molecular structure (A) and of the crystal packing along the axis $\mathbf{b}$ (B) of 1,2,3,4,5,6,7,8-octafluorofluorene, 1. Thermal ellipsoids are drawn at $30 \%$ probability level.

Figure 3. View of the molecular structure (A) and of the crystal packing along the axis b (B) of 1,2,3,4,5,6,7,8-octafluoro-9(pentafluorophenyl)fluorene, 8. Thermal ellipsoids are drawn at $30 \%$ probability level.

Compound 1 (Fig. 2A) possesses a twofold symmetry and is essentially planar, the maximum deviation $(0.03 \AA)$ occurring at $\mathrm{F}(4)$. As shown in Fig. 2B, the molecules align along the $\left(\begin{array}{lll}1 & 0 & 1\end{array}\right)$ plane.

For what concerns $\mathbf{8}$, the molecules are arranged in infinite columns parallel to axis $\mathbf{b}$, the octafluorofluorenyl moieties being

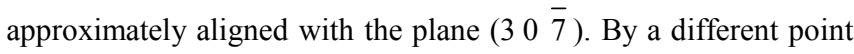
of view, the same molecules are distributed along two planes: one of them is defined by the octafluorofluorenyl frames, the maximum deviation being $0.08 \AA$ at $\mathrm{F}(7)$, while the second plane is defined by the pentafluorophenyl rings [max deviation $0.02 \AA$ at $F(17)$ ]. Importantly, the two planes form a dihedral angle of $83.5^{\circ}$, resembling the non-equivalence of the orto and meta-positions within the aryl ring, which is observed also in solution even at room temperature (see above). It is noteworthy that a molecular layout analogous to that found for $\mathbf{8}$ is regularly exhibited by species containing the 9 -aryl-fluorene unit, ${ }^{[14]}$ the dihedral angle between the aryl and the fluorine units ranging between 72.9 and $89.1^{\circ}$. The molecular structure of $\mathbf{1 1}$ is shown in Figure 4A, whereas bond distances and angles are provided as Supporting Information. The structure of the two equivalent fluorenyl moieties is similar to that observed in non-fluorinated 9,9'-bifluorenyl ${ }^{[15]}$ and in $1,1^{\prime}, 2,2^{\prime}, 3,3^{\prime}, 4,4^{\prime}, 5,5^{\prime}, 6,6^{\prime}, 7,7^{\prime}, 8,8^{\prime}$-hexadecachloro-9,9'bifluorenyl. ${ }^{[16]}$ Likewise these compounds, 11 shows a gauche conformation, and only slight differences in the torsion angle $\mathrm{C}(1) \mathrm{C}(13) \mathrm{C}(14) \mathrm{C}(26)$ are displayed in the three cases: the value of this angle is $61.9^{\circ}$ in $9,9^{\prime}$-bifluorenyl,[15] $67.6^{\circ}$ and $74.4^{\circ}$ in the two independent molecules of $1,1^{\prime}, 2,2^{\prime}, 3,3^{\prime}, 4,4^{\prime}, 5,5^{\prime}, 6,6^{\prime}, 7,7^{\prime}, 8,8^{\prime}-$ hexadecachloro-9,9'-bifluorenyl,[16] and $72.5^{\circ}$ in $\mathbf{1 1}$.

Figure 4 about here

Figure 4. View of the molecular structure (A) and of the crystal packing along the axis $\mathbf{b}$ (B) of $1,1^{\prime}, 2,2^{\prime}, 3,3^{\prime}, 4,4^{\prime}, 5,5^{\prime}, 6,6^{\prime}, 7,7^{\prime}, 8,8^{\prime}$-hexadecafluoro9,9'-bifluorenyl, 11. Thermal ellipsoids are drawn at $30 \%$ probability level.

As a general consideration, the $\mathrm{X}$ ray structures of $\mathbf{1 , 8 , 1 1}$ display similar average $\mathrm{C}-\mathrm{C}$ bond distances, within the aryl rings, which resemble the corresponding values observed in the ions $\left[\mathrm{B}\left(\mathrm{C}_{6} \mathrm{~F}_{5}\right)_{4}\right]^{-[17]}$ and $\left[\mathrm{BH}\left(\mathrm{C}_{6} \mathrm{~F}_{5}\right)_{3}\right]^{-[18]}$ The $\mathrm{C}\left(s p^{3}\right)-\mathrm{C}$ distances, Table 
3 , do not vary significantly on going from phenyl ${ }^{[19]}$ (or $p$-tolyl$\left.{ }^{[20]}\right)$ substituted fluorenes to 8 . The increase of the $\mathrm{C}\left(s p^{3}\right)-\mathrm{C}$ distances on going from the 9-aryl- to the 9-fluorenyl substituted species is due to fact that, in the latter, both these carbon atoms are $s p^{3}$-hybridized. Moreover, the $\mathrm{C}\left(s p^{2}\right)-\mathrm{F}$ lengths appear comparable to those found in perfluorinated organic molecules. ${ }^{[21]}$

Table 3. $\mathrm{C}\left(s p^{3}\right)-\mathrm{C}(R)$ distances $(\AA)$ in selected 9-substituted fluorenes.

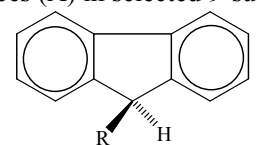

\begin{tabular}{|c|c|c|}
\hline $\mathrm{R}$ & $\begin{array}{c}\mathrm{C}\left(s p^{3}\right)-\mathrm{C}(R) \\
\text { distance } \\
(\AA)\end{array}$ & Ref. \\
\hline $\mathrm{C}_{6} \mathrm{H}_{5}$ & $1.523(6)$ & {$[19]$} \\
\hline$p-\mathrm{CH}_{3} \mathrm{C}_{6} \mathrm{H}_{4}$ & $1.515(7)$ & {$[20]$} \\
\hline $\mathrm{C}_{6} \mathrm{~F}_{5}$ & $1.521(4)$ & This work \\
\hline $\mathrm{C}_{13} \mathrm{H}_{9}$ & $1.542(5) ; 1.539(6)$ & {$[16 \mathrm{a}, \mathrm{d}]$} \\
\hline $\mathrm{C}_{13} \mathrm{HF}_{8}$ & $1.577(3)$ & This work \\
\hline
\end{tabular}

\section{Conclusions}

Some novel octafluorofluorene derivatives have been described here for the first time as prepared in high yields by standard routes.

Variable temperature ${ }^{19} \mathrm{~F}$-NMR solution studies performed on octafluoro-9-arylfluorenes have allowed to estimate kinetic parameters related to the aryl ring rotational motion. According to these studies, the substitution of one hydrogen with one hydroxyl group at the quaternary carbon makes the rotation of the aryl moiety around the $\mathrm{C}\left(s p^{3}\right)$-aryl bond more rapid, in agreement with previous reports regarding analogous non-fluorinated systems. Moreover, variable temperature NMR experiments carried out in solvents of different polarities have ruled out the possibility that a dissociative mechanism is involved in the aryl rotational process.

The $\mathrm{X}$ ray solid state structures determined for $1,2,3,4,5,6,7,8$ octafluorofluorene, 1,2,3,4,5,6,7,8-octafluoro-9-(pentafluorophe-

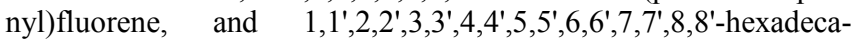
fluoro-9,9'-bifluorenyl represent the first crystallographic reports concerning octafluorofluorene compounds. Comparisons of the structural features with those available for all-hydrogen analogous molecules have pointed out that the substitution with fluorine atoms does not determine dramatic changes in the geometry and in the crystal packing.

\section{Experimental Section}

\section{General Considerations.}

Unless otherwise stated, all the operations were carried out under atmosphere of prepurified argon. Solvents were dried by conventional methods prior to use. ${ }^{1} \mathrm{H}$ and ${ }^{19} \mathrm{~F}$ NMR spectra at $298 \mathrm{~K}$ were recorded on Varian Gemini 200BB instrument $(200 \mathrm{MHz}$ for ${ }^{1} \mathrm{H}$ and $188 \mathrm{MHz}$ for ${ }^{19} \mathrm{~F}$ ), while variable temperature ${ }^{19} \mathrm{~F}$ NMR spectra were recorded on Varian VXR $300\left(282 \mathrm{MHz}\right.$ for $\left.{ }^{19} \mathrm{~F}\right)$. TMS was used as standard for ${ }^{1} \mathrm{H}-\mathrm{NMR}$ spectra, whereas $\mathrm{CFCl}_{3}$ was used as standard for ${ }^{19} \mathrm{~F}$ NMR spectra. The compounds $1,2,3,4,5,6,7,8-$ octafluorofluorene, 1,[1c] 1,2,3,4,5,6,7,8-octafluorofluorenone, $\left.{ }^{[22}\right]$ and 4-Br-nonafluoro-1,1'-biphenyl ${ }^{[23]}$ were prepared according to literature procedures.

Preparation of $1,2,3,4,5,6,7,8-0 c t a f l u o r o-9-h y d r o x y-9-$ arylfluorene derivatives, 2-5. Only the preparation of 1,2,3,4,5,6,7,8-octafluoro-9-hydroxy-9-[2,4-bis(trifluoromethyl) phenyl]fluorene, 2, is described in detail, those of compounds 3-5 being performed in a similar way. A solution of 1-bromo-2,4bis(trifluoromethyl)benzene $(5.00 \mathrm{~g}, 17.1 \mathrm{mmol})$, in diethyl ether $(100 \mathrm{ml})$, was added to a $2.5 \mathrm{M}$ solution of butyl-lithium in diethyl ether $\left(7.00 \mathrm{~mL} ; 17.5 \mathrm{mmol}\right.$ of butyl-lithium), at $c a .-75^{\circ} \mathrm{C}$. After 1 $\mathrm{h}$ stirring at this temperature, 1,2,3,4,5,6,7,8-octafluorofluorenone $(6.00 \mathrm{~g}, 17.84 \mathrm{mmol})$ was added. The mixture was additionally stirred for $1 \mathrm{~h}$ and then hydrolyzed with water. The resulting two phases were separated, then the aqueous liquor was washed with diethyl ether $(2 \times 50 \mathrm{~mL})$. The ether solutions were unified and dried over $\mathrm{Na}_{2} \mathrm{SO}_{4}$. The solvent was evaporated to dryness and the residue was treated with cold petroleum ether. The solution obtained was filtered and then dried in vacuo, so obtaining $2.55 \mathrm{~g}$ (56\% yield) of 2 as colourless crystalline solid. $\mathrm{C}_{21} \mathrm{H}_{4} \mathrm{~F}_{14} \mathrm{O}$ (538.23): calcd. C 46.86, H 0.75; found C 46.91, H 0.71. ${ }^{1} \mathrm{H}-\mathrm{NMR}$ $\left(\mathrm{CDCl}_{3}\right): \delta 8.80\left(\mathrm{~d},{ }^{3} J_{\mathrm{HH}}=8.1 \mathrm{~Hz}, 2 \mathrm{H}, \mathrm{H} 3^{\prime \prime}\right) ; 8.00\left(\mathrm{~d},{ }^{3} J_{\mathrm{HH}}=8.1\right.$ $\mathrm{Hz}, 2 \mathrm{H}, \mathrm{H} 2^{\prime \prime}$ ); 7.90 (s, $\left.1 \mathrm{H}, \mathrm{H} 3^{\prime}\right) ; 3.00$ (s, $\left.1 \mathrm{H}, \mathrm{OH}\right) \mathrm{ppm} .{ }^{19} \mathrm{~F}-\mathrm{NMR}$ $\left(\mathrm{CDCl}_{3}\right.$, see Scheme 1 for the fluorine atoms numbering): $\delta-63.2$, -58.2 (br, $\left.6 \mathrm{~F}, \mathrm{CF}_{3}\right) ;-133.3\left(\mathrm{~d},{ }^{3} \mathrm{~J}_{\mathrm{FF}}=19.5 \mathrm{~Hz}, 2 \mathrm{~F}, \mathrm{~F} 1+\mathrm{F} 8\right)$; $-143.3\left(\mathrm{~d},{ }^{3} \mathrm{~J}_{\mathrm{FF}}=19 \mathrm{~Hz}, 2 \mathrm{~F}, \mathrm{~F} 4+\mathrm{F} 5\right) ;-150.2$ (m, 2 F, F2 + F7); $-152.0(\mathrm{~m}, 2 \mathrm{~F}, \mathrm{~F} 3+\mathrm{F} 6)$.

1,2,3,4,5,6,7,8-octafluoro-9-hydroxy-9-[3,5-

bis(trifluoromethyl)phenyl|fluorene, 3 . Colourless microcrystalline solid, $95 \%$ yield from 3,5bis(trifluoromethyl)phenyl-lithium, freshly prepared from 1bromo-3,5-bis(trifluoromethyl)benzene, and 1,2,3,4,5,6,7,8octafluorofluorenone, after purification on a silica gel column [eluent: petroleum ether $/$ acetone $=90 / 10(v / v)] . \mathrm{C}_{21} \mathrm{H}_{4} \mathrm{~F}_{14} \mathrm{O}$ (538.23): calcd. C 46.86, H 0.75; found C 46.69, H 0.78. ${ }^{1} \mathrm{H}-\mathrm{NMR}$ $\left(\mathrm{CDCl}_{3}\right): \delta 7.87$ (s, $\left.1 \mathrm{H}, \mathrm{H} 4^{\prime}\right) ; 7.84$ (s, $\left.2 \mathrm{H}, \mathrm{H} 2^{\prime}+\mathrm{H} 2^{\prime \prime}\right) ; 3.20$ (s, 1 $\mathrm{H}, \mathrm{OH})$ ppm. ${ }^{19} \mathrm{~F}-\mathrm{NMR}\left(\mathrm{CDCl}_{3}\right.$, see Scheme 1 for the fluorine atoms numbering): $\delta-62.9\left(\mathrm{~s}, 6 \mathrm{~F}, \mathrm{CF}_{3}\right) ;-132.6\left(\mathrm{~d},{ }^{3} \mathrm{~J}_{\mathrm{FF}}=20.0 \mathrm{~Hz}\right.$, $2 \mathrm{~F}, \mathrm{~F} 1+\mathrm{F} 8) ;-142.1\left(\mathrm{~d},{ }^{3} \mathrm{~J}_{\mathrm{FF}}=19.8 \mathrm{~Hz}, 2 \mathrm{~F}, \mathrm{~F} 4+\mathrm{F} 5\right) ;-149.3(\mathrm{~m}$, 2 F, F2 + F7); -150.5 (m, 2 F, F3 + F6) ppm.

\section{1,2,3,4,5,6,7,8-octafluoro-9-hydroxy-9-(pentafluorophenyl)}

fluorene, 4. Colourless microcrystalline solid, $93 \%$ yield from pentafluorophenyl lithium, freshly prepared from 1-bromopentafluorobenzene, and 1,2,3,4,5,6,7,8-octafluorofluorenone. $\mathrm{C}_{19} \mathrm{HF}_{13} \mathrm{O}$ (492.19): calcd. C 46.36, H 0.20; found C 46.31, H 0.22. ${ }^{1} \mathrm{H}-\mathrm{NMR}\left(\mathrm{CDCl}_{3}\right): \delta 3.75(\mathrm{~s}, 1 \mathrm{H}, \mathrm{OH}) \mathrm{ppm} .{ }^{19} \mathrm{~F}-\mathrm{NMR}\left(\mathrm{CDCl}_{3}\right.$, see Scheme 1 for the fluorine atoms numbering): $\delta-133.0\left(\mathrm{~d},{ }^{3} \mathrm{~J}_{\mathrm{FF}}=\right.$ $19.5 \mathrm{~Hz}, 2 \mathrm{~F}, \mathrm{~F} 1+\mathrm{F} 8),-141.0\left(\mathrm{~d},{ }^{3} \mathrm{~J}_{\mathrm{FF}}=19.3 \mathrm{~Hz}, 2 \mathrm{~F}, \mathrm{~F} 2^{\prime}+\mathrm{F} 2^{\prime \prime}\right)$, $-143.8\left(\mathrm{~d},{ }^{3} \mathrm{~J}_{\mathrm{FF}}=19.5 \mathrm{~Hz}, 2 \mathrm{~F}, \mathrm{~F} 4+\mathrm{F} 5\right),-149.7$ (m, 2 F, F2 + F7), $-151.4(\mathrm{~m}, 2 \mathrm{~F}, \mathrm{~F} 3+\mathrm{F} 6),-151.7\left(\mathrm{t},{ }^{3} \mathrm{~J}_{\mathrm{FF}}=21.1 \mathrm{~Hz}, 1 \mathrm{~F}, \mathrm{~F} 4{ }^{\prime}\right)$, -159.8 (m, 2 F, F3' + F3') ppm. ${ }^{19}$ F-NMR (THF-d ${ }^{8}$, see Scheme 1 for the fluorine atoms numbering): $\delta-131.3\left(\mathrm{~d},{ }^{3} \mathrm{~J}_{\mathrm{FF}}=19.8 \mathrm{~Hz}, 2 \mathrm{~F}\right.$, $\mathrm{F} 1+\mathrm{F} 8),-135.9\left(\mathrm{~d},{ }^{3} \mathrm{~J}_{\mathrm{FF}}=19.3 \mathrm{~Hz}, 2 \mathrm{~F}, 2 \mathrm{~F}, \mathrm{~F} 2^{\prime}+\mathrm{F} 2^{\prime \prime}\right),-140.2(\mathrm{~d}$, $\left.{ }^{3} \mathrm{~J}_{\mathrm{FF}}=19.5 \mathrm{~Hz}, 2 \mathrm{~F}, \mathrm{~F} 4+\mathrm{F} 5\right),-149.3(\mathrm{~m}, 2 \mathrm{~F}, \mathrm{~F} 2+\mathrm{F} 7),-150.0(\mathrm{~m}$, $2 \mathrm{~F}, \mathrm{~F} 3+\mathrm{F} 6),-151.4\left(\mathrm{t},{ }^{3} \mathrm{~J}_{\mathrm{FF}}=21.2 \mathrm{~Hz}, 1 \mathrm{~F}, \mathrm{~F} 4^{\prime}\right),-159.0(\mathrm{~m}, 2 \mathrm{~F}$, $\mathrm{F} 3^{\prime}+\mathrm{F}^{\prime \prime}$ ) $\mathrm{ppm}$.

\section{1,2,3,4,5,6,7,8-octafluoro-9-hydroxy-9-[(nonafluoro)-4-}

biphenylyl]fluorene, 5. Colourless microcrystalline solid, $96 \%$ yield from (nonafluoro)-4-biphenylyl lithium, freshly prepared from 4-bromo(nonafluoro)-4-biphenylyl, and 1,2,3,4,5,6,7,8octafluorofluorenone, after purification on a silica gel column [eluent: petroleum ether / acetone $90 / 10(v / v)] . \mathrm{C}_{25} \mathrm{HF}_{17} \mathrm{O}$ (640.25): calcd. C 46.90, H 0.16; found C 46.81, H 0.13. ${ }^{1} \mathrm{H}-\mathrm{NMR}$ $\left(\mathrm{CDCl}_{3}\right): \delta 3.35(\mathrm{~s}, 1 \mathrm{H}, \mathrm{OH}) \mathrm{ppm} .{ }^{19} \mathrm{~F}-\mathrm{NMR}\left(\mathrm{CDCl}_{3}\right.$, see Scheme 1 for the fluorine atoms numbering): $\delta-133.0(\mathrm{~m}, 2 \mathrm{~F}, \mathrm{~F} 1+\mathrm{F} 8)$, $-133.6\left(\mathrm{~d},{ }^{3} \mathrm{~J}_{\mathrm{FF}}=21.5 \mathrm{~Hz}, 1 \mathrm{~F}, \mathrm{~F} 2{ }^{\prime}\right),-136.3\left(\mathrm{~d},{ }^{3} \mathrm{~J}_{\mathrm{FF}}=21.5 \mathrm{~Hz}, 1 \mathrm{~F}\right.$, $\left.\mathrm{F}^{\prime \prime}{ }^{\prime}\right),-137.9\left(\mathrm{~d},{ }^{3} \mathrm{~J}_{\mathrm{FF}}=19.8 \mathrm{~Hz}, 1 \mathrm{~F}, \mathrm{~F} 4^{\prime}\right),-138.3\left(\mathrm{~d},{ }^{3} \mathrm{~J}_{\mathrm{FF}}=19.5 \mathrm{~Hz}\right.$, $\left.1 \mathrm{~F}, \mathrm{~F} 4{ }^{\prime \prime}\right),-141.7$ (m, 2 F, F4 + F5), -149.9 (m, 2 F, F2 + F7), $-151.4\left(\mathrm{~m}, 3 \mathrm{~F}, \mathrm{~F} 3, \mathrm{~F} 6+\mathrm{F} 66^{\prime}\right),-152.6\left(\mathrm{~d},{ }^{3} \mathrm{~J}_{\mathrm{FF}}=20.0 \mathrm{~Hz}, 1 \mathrm{~F}, \mathrm{~F} 3^{\prime}\right)$, $-153.9\left(\mathrm{~d},{ }^{3} \mathrm{~J}_{\mathrm{FF}}=19.7 \mathrm{~Hz}, 1 \mathrm{~F}, \mathrm{~F} 3^{\prime \prime}\right),-163.3\left(\mathrm{~m}, 2 \mathrm{~F}, \mathrm{~F} 5^{\prime}+\mathrm{F} 5^{\prime \prime}\right)$ ppm. ${ }^{19} \mathrm{~F}-\mathrm{NMR}\left(\mathrm{THF}-\mathrm{d}^{8}\right.$, see Scheme 1 for the fluorine atom numbering): $\delta-131.0(\mathrm{~m}, 2 \mathrm{~F}, \mathrm{~F} 1+\mathrm{F} 8),-131.9\left(\mathrm{~d},{ }^{3} \mathrm{~J}_{\mathrm{FF}}=21.1 \mathrm{~Hz}\right.$, $\left.1 \mathrm{~F}, \mathrm{~F} 2{ }^{\prime}\right),-132.7\left(\mathrm{~d},{ }^{3} \mathrm{~J}_{\mathrm{FF}}=21.0 \mathrm{~Hz}, 1 \mathrm{~F}, \mathrm{~F} 2^{\prime \prime}\right),-134.2\left(\mathrm{~d},{ }^{3} \mathrm{~J}_{\mathrm{FF}}=\right.$ $\left.21.0 \mathrm{~Hz}, 1 \mathrm{~F}, \mathrm{~F} 4^{\prime}\right),-134.4\left(\mathrm{~d},{ }^{3} \mathrm{~J}_{\mathrm{FF}}=21.1 \mathrm{~Hz}, 1 \mathrm{~F}, \mathrm{~F} 4^{\prime \prime}\right),-138.5(\mathrm{~m}$, 2 F, F4 + F5), -148.6 (m, 2 F, F2 + F7), -149.6 (m, 2 F, F3 + F6), $-151.9\left(\mathrm{t},{ }^{3} \mathrm{~J}_{\mathrm{FF}}=21.0 \mathrm{~Hz}, 1 \mathrm{~F}, \mathrm{~F} 6^{\prime}\right),-148.9\left(\mathrm{~d},{ }^{3} \mathrm{~J}_{\mathrm{FF}}=21.0 \mathrm{~Hz}, 1 \mathrm{~F}\right.$, F3'), $-150.7\left(\mathrm{~d},{ }^{3} \mathrm{~J}_{\mathrm{FF}}=19.6 \mathrm{~Hz}, 1 \mathrm{~F}, \mathrm{~F} 3^{\prime \prime}\right),-161.2\left(\mathrm{~m}, 2 \mathrm{~F}, \mathrm{~F} 5^{\prime}+\right.$ F5") ppm. 


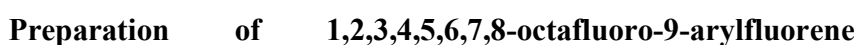
derivatives, 6-8. Only the preparation of $1,2,3,4,5,6,7,8$ octafluoro-9-[2,4-bis(trifluoromethyl)phenyl]fluorene, $\mathbf{6}, \quad$ is described in detail, those of compounds 7-8 being performed in a similar way. A mixture of $2(0.950 \mathrm{~g}, 1.85 \mathrm{mmol})$ and $\mathrm{PBr}_{3}(10.0$ $\mathrm{mL}, 0.106 \mathrm{~mol})$ was heated at $110-120{ }^{\circ} \mathrm{C}$ for 40 minutes $(30$ minutes in the case of 8). Hence, the reaction mixture was hydrolysed on ice, and washed with diethylether $(3 \times 40 \mathrm{~mL})$. The combined ethereal extracts were washed with a $10 \%$ aqueous solution of $\mathrm{NaHCO}_{3}$, and then were dried over $\mathrm{Na}_{2} \mathrm{SO}_{4}$, filtered and finally dried in vacuo. The residue so obtained was dissolved in 20 $\mathrm{mL}$ of acetic acid, and treated with zinc $(1.05 \mathrm{~g}, 16.1 \mathrm{mmol})$. The resulting mixture was stirred for $1 \mathrm{~h}$ at $25^{\circ} \mathrm{C}$, hydrolyzed in water, and then washed with diethyl ether $(2 \times 30 \mathrm{~mL})$. The ethereal extracts were unified, and washed with a $10 \%$ aqueous solution of $\mathrm{NaHCO}_{3}$. Afterwards, the ethereal solution was dried over $\mathrm{Na}_{2} \mathrm{SO}_{4}$, filtered and dried in vacuo. The raw material was purified by chromatography on a silica gel column using petroleum ether as eluent. Compound $\mathbf{6}$ was obtained as a colourless crystalline material upon removal of the solvent $(0.61 \mathrm{~g}, 72 \%$ yield $)$. $\mathrm{C}_{21} \mathrm{H}_{4} \mathrm{~F}_{14}$ (522.23): calcd. C 48.30, H 0.77; found C 48.36, H 0.80 . ${ }^{1} \mathrm{H}-\mathrm{NMR}\left(\mathrm{CDCl}_{3}\right): \delta 8.05\left(\mathrm{~s}, 1 \mathrm{H}, \mathrm{H} 3^{\prime}\right) ; 7.60\left(\mathrm{~d},{ }^{3} J_{\mathrm{HH}}=8.2 \mathrm{~Hz}, 1 \mathrm{H}\right.$, $\left.\mathrm{H} 2^{\prime \prime}\right) ; 6.70\left(\mathrm{~d},{ }^{3} J_{\mathrm{HH}}=8.2 \mathrm{~Hz}, 2 \mathrm{H}, \mathrm{H} 3^{\prime \prime}\right) ; 5.86(\mathrm{~s}-\mathrm{br}, 1 \mathrm{H}, \mathrm{CH}) \mathrm{ppm}$. ${ }^{19} \mathrm{~F}-\mathrm{NMR}\left(\mathrm{CDCl}_{3}\right.$, see Scheme 2 for the fluorine atoms numbering): $\delta-58.3,-63.2\left(\mathrm{~s}, 6 \mathrm{~F}, \mathrm{CF}_{3}\right) ;-133.9\left(\mathrm{~d},{ }^{3} \mathrm{~J}_{\mathrm{FF}}=20 \mathrm{~Hz}, 2\right.$ $\mathrm{F}, \mathrm{F} 1+\mathrm{F} 8),-140.9\left(\mathrm{~d},{ }^{3} \mathrm{~J}_{\mathrm{FF}}=19.5 \mathrm{~Hz}, 2 \mathrm{~F}, \mathrm{~F} 4+\mathrm{F} 5\right),-152.3(\mathrm{~m}, 4$ $\mathrm{F}, \mathrm{F} 2+\mathrm{F} 7+\mathrm{F} 3+\mathrm{F} 6)$ ppm.

\section{1,2,3,4,5,6,7,8-octafluoro-9-[(3,5--bis(trifluoromethyl)phenyl]}

fluorene, 7. Colourless microcrystalline solid, $77 \%$ yield from 3. $\mathrm{C}_{21} \mathrm{H}_{4} \mathrm{~F}_{14}$ (522.23): calcd. C 48.30, H 0.77; found C 48.40, $\mathrm{H} 0.81$. ${ }^{1} \mathrm{H}-\mathrm{NMR}\left(\mathrm{CDCl}_{3}\right): \delta 7.84\left(\mathrm{~s}, 1 \mathrm{H}, \mathrm{H} 4^{\prime}\right) ; 7.53\left(\mathrm{~s}, 2 \mathrm{H}, \mathrm{H} 2^{\prime}+\mathrm{H}^{\prime \prime}\right)$; 5.57 (s-br, $1 \mathrm{H}, \mathrm{CH}) \mathrm{ppm} .{ }^{19} \mathrm{~F}-\mathrm{NMR}\left(\mathrm{CDCl}_{3}\right.$, see Scheme 2 for the fluorine atoms numbering): $\delta-63.0\left(\mathrm{~s}, 6 \mathrm{~F}, \mathrm{CF}_{3}\right) ;-133.5\left(\mathrm{~d},{ }^{3} \mathrm{~J}_{\mathrm{FF}}=\right.$ $19 \mathrm{~Hz}, 2 \mathrm{~F}, \mathrm{~F} 1+\mathrm{F} 8) ;-141.2\left(\mathrm{~d},{ }^{3} \mathrm{~J}_{\mathrm{FF}}=19.8 \mathrm{~Hz}, 2 \mathrm{~F}, \mathrm{~F} 4+\mathrm{F} 5\right)$; -151.9 (m, 2 F, F2 + F7); -152.2 (m, 2 F, F3 + F6) ppm.

$\mathbf{1 , 2 , 3 , 4 , 5 , 6 , 7 , 8 - o c t a f l u o r o - 9 - ( p e n t a f l u o r o p h e n y l ) f l u o r e n e , ~}$

Colourless microcrystalline solid, $84 \%$ yield from $\mathbf{4}$, after chromatography on silica gel [eluent: petroleum ether $/ \mathrm{CH}_{2} \mathrm{Cl}_{2} 98$ / $2(v / v)] . \mathrm{C}_{19} \mathrm{HF}_{13}$ (476.19): calcd. C 47.92, H 0.21; found $\mathrm{C} 47.81$, $\mathrm{H} 0.19 .{ }^{1} \mathrm{H}-\mathrm{NMR}\left(\mathrm{CDCl}_{3}\right): \delta 5.78$ (s-br, $\left.1 \mathrm{H}, \mathrm{CH}\right) \mathrm{ppm} .{ }^{19} \mathrm{~F}-\mathrm{NMR}$ : see Table 1 for the assignment of the fluorine resonances and Scheme 2 for the fluorine atoms numbering.

Preparation of octafluoro-9-hydroxyfluorene, 9. A suspension of 1,2,3,4,5,6,7,8-octafluorofluorenone (2.03 g, $6.26 \mathrm{mmol})$, in acetic acid $(20 \mathrm{~mL})$, was treated with finely divided zinc $(0.998 \mathrm{~g}$, $15.3 \mathrm{mmol}$ ). The mixture was stirred at room temperature for 1 hour, then a TLC analysis [eluent: petroleum ether/acetone $8 / 2$ $(v / v)$ ] revealed that complete consumption of starting fluorenone had occurred. Subsequently, water $(150 \mathrm{~mL})$ was added to the mixture, then the resulting mixture was treated with diethyl ether (3 x $50 \mathrm{~mL}$ ). The solvent was removed from the extracted ethereal materials, thus colourless crystalline compound $9(1.88 \mathrm{~g}, 92 \%$ yield) was obtained. $\mathrm{C}_{13} \mathrm{H}_{2} \mathrm{~F}_{8} \mathrm{O}$ (326.14): calcd. C 47.87, $\mathrm{H} 0.62$; found $\mathrm{C} 47.73, \mathrm{H} 0.63 .{ }^{1} \mathrm{H}-\mathrm{NMR}\left(\mathrm{CDCl}_{3}\right): \delta 6.16(\mathrm{~s}, 1 \mathrm{H}, \mathrm{CH})$, $2.62(\mathrm{~s}, 1 \mathrm{H}, \mathrm{OH}) \mathrm{ppm} .{ }^{19} \mathrm{~F}-\mathrm{NMR}\left(\mathrm{CDCl}_{3}\right.$, see Scheme 3 for the fluorine atoms numbering): $\delta-134.3(\mathrm{~m}, 2 \mathrm{~F}, \mathrm{~F} 1+\mathrm{F} 8) ;-142.5(\mathrm{~d}$, $\left.{ }^{3} \mathrm{~J}_{\mathrm{FF}}=19.3 \mathrm{~Hz}, 2 \mathrm{~F}, \mathrm{~F} 4+\mathrm{F} 5\right) ;-151.3(\mathrm{~m}, 2 \mathrm{~F}, \mathrm{~F} 2+\mathrm{F} 7) ;-152.8(\mathrm{~m}$, 2 F, F3 + F6) ppm.

Preparation of 9-bromo-octafluorofluorene, 10. Compound 9 $(2.05 \mathrm{~g}, 6.29 \mathrm{mmol})$ and $\mathrm{PBr}_{3}(10 \mathrm{~mL}, 0.11 \mathrm{~mol})$ were mixed together and heated at $80{ }^{\circ} \mathrm{C}$ for $1 \mathrm{~h}$. The reaction mixture was hydrolysed on ice, and then washed with diethyl ether $(3 \times 30 \mathrm{~mL})$. The ethereal extracts were washed with water $(4 \times 20 \mathrm{~mL})$, until the water phase reached an almost neutral $\mathrm{pH}$. Hence, the ethereal solution was dried over $\mathrm{Na}_{2} \mathrm{SO}_{4}$, filtered and finally dried in vacuo. Compound 10 (2.06 g, $81 \%$ yield) was obtained as a microcrystalline colourless material. $\mathrm{C}_{13} \mathrm{HBrF}_{8}$ (389.04): calcd. $\mathrm{C}$ 40.13, H 0.26; found C 40.22, H 0.21. ${ }^{1} \mathrm{H}-\mathrm{NMR}\left(\mathrm{CDCl}_{3}\right): \delta 6.14$ (s, $1 \mathrm{H}, \mathrm{CH}) \mathrm{ppm} .{ }^{19} \mathrm{~F}-\mathrm{NMR}\left(\mathrm{CDCl}_{3}\right.$, see Scheme 3 for the fluorine

atoms numbering): $\delta-133.8(\mathrm{~m}, 2 \mathrm{~F}, \mathrm{~F} 1+\mathrm{F} 8) ;-137.2\left(\mathrm{~d},{ }^{3} \mathrm{~J}_{\mathrm{FF}}=19\right.$ $\mathrm{Hz}, 2$ F, F4 + F5); -150.5 (m, 2 F, F2 + F7); -152.5 (m, 2 F, F3 + F6) ppm.

Preparation of $1,1^{\prime}, 2,2^{\prime}, 3,3^{\prime}, 4^{\prime}, 4^{\prime}, 5^{\prime}, 5^{\prime}, 6,6^{\prime}, 7^{\prime}, 7^{\prime}, 8,8^{\prime}$-hexadecafluoro-9,9'-bifluorenyl, 11. A solution of $\mathbf{1 0}(1.98 \mathrm{~g}, 4.89 \mathrm{mmol})$, in diethylether $(50 \mathrm{~mL})$, was treated at room temperature with a 1.0 $\mathrm{M}$ solution of sec-butylmagnesium chloride in diethylether (9.80 $\mathrm{mL}, 9.80 \mathrm{mmol})$. After stirring for 2 hours at room temperature, the reaction mixture was hydrolysed with ice and then treated with $\mathrm{CH}_{2} \mathrm{Cl}_{2}$ ( $\mathrm{ca}$. $500 \mathrm{~mL}$ ). The organic phase was isolated and dried over $\mathrm{Na}_{2} \mathrm{SO}_{4}$, hence the solvent was removed in vacuo. The resulting residue was dissolved in toluene at $c a .60^{\circ} \mathrm{C}$, then the solution was filtered through Celite/activated carbon, and finally cooled to room temperature. Well-shaped crystals formed, and these were isolated by filtration and dried in vacuo. Yield: $1.93 \mathrm{~g}$, $64 \% . \mathrm{C}_{26} \mathrm{H}_{2} \mathrm{~F}_{16}$ (618.27): calcd. C 50.51, H 0.33; found C 50.41, H 0.37. ${ }^{1} \mathrm{H}-\mathrm{NMR}\left(\mathrm{CDCl}_{3}\right): \delta 5.40(\mathrm{~s}, 2 \mathrm{H}, \mathrm{CH}) \mathrm{ppm} .{ }^{19} \mathrm{~F}-\mathrm{NMR}$ $\left(\mathrm{CDCl}_{3}\right.$, see Scheme 3 for the fluorine atoms numbering): $\delta-133.2$ $\left(\mathrm{m}, 4 \mathrm{~F}, \mathrm{~F} 1+\mathrm{F} 8+\mathrm{F} 1^{\prime}+\mathrm{F} 8^{\prime}\right) ;-138 \div-142\left(\mathrm{~d}^{3} \mathrm{~J}_{\mathrm{FF}}=19 \mathrm{~Hz}, \mathrm{~F} 4+\right.$ $\left.\mathrm{F} 5+\mathrm{F}^{\prime}+\mathrm{F}^{\prime}\right) ;-151.6\left(\mathrm{~m}, 4 \mathrm{~F}, \mathrm{~F} 2+\mathrm{F} 7+\mathrm{F} 2^{\prime}+\mathrm{F} 7^{\prime}\right) ;-152.7(\mathrm{~m}, 4$ $\left.\mathrm{F}, \mathrm{F} 3+\mathrm{F} 6+\mathrm{F} 3^{\prime}+\mathrm{F} 6^{\prime}\right) \mathrm{ppm}$.

Crystal structure solution and refinement of compounds 1,8 , and 11. Data were collected at $293 \mathrm{~K}$ on a Bruker P4 diffractometer, operating with a graphite-monochromated Mo- $K_{\alpha}$ radiation. Colourless prisms of $\mathbf{1}$ or $\mathbf{1 1}$ or colourless platelets of $\mathbf{8}$ were glued on the tip of a glass fiber for lattice parameters and intensity data collection. The results are summarized in Table 4. The intensity data collection was carried out with the $\omega / 2 \theta$ scan mode; three standard reflections being measured every 97 measurements to check sample decay. The intensities were corrected for Lorentz and polarization effects. An absorption correction by the $\psi$-scan method ${ }^{[24]}$ was applied only to the intensities of compound $\mathbf{8}$. The structure solutions was obtained by direct methods ${ }^{[25]}$ and refined with full-matrix least-squares on $F^{2}{ }^{[25]}$ Some other utilities contained in the WINGX suite ${ }^{[26]}$ were also used.

The structure solution was obtained in the centrosymmetric $C 2 / c$ space group for compounds $\mathbf{1}$ and $\mathbf{8}$ and in the $P 2{ }_{1} / c$ space group for compound 11. The asymmetric unit of 1 contains half molecule riding a twofold axis. Either in $\mathbf{1}$ or in $\mathbf{8}$ or in $\mathbf{1 1}$ the hydrogen atoms were localized in the difference Fourier map and refined without constraints. The reliability factors resulting from the final refinement cycle are listed in Table 4.

Table 4. Crystal data for compounds $\mathbf{1}, \mathbf{8}$ and $\mathbf{1 1}$.

\begin{tabular}{|c|c|c|c|}
\hline Compound & 1 & 8 & 11 \\
\hline Empirical formula & $\mathrm{C}_{19} \mathrm{HF}_{13}$ & $\mathrm{C}_{13} \mathrm{H}_{2} \mathrm{~F}_{8}$ & $\mathrm{C}_{26} \mathrm{H}_{2} \mathrm{~F}_{16}$ \\
\hline F W & 476.20 & 310.15 & 618.28 \\
\hline$T / \mathrm{K}$ & $293(2)$ & $293(2)$ & $293(2)$ \\
\hline$\lambda / \AA$ & 0.71073 & 0.71073 & 0.71073 \\
\hline Crystal system & Monoclinic & Monoclinic & Monoclinic \\
\hline Space group & C2/c (No. 15) & $C 2 / c$ (No. 15) & $P 2_{1} / c$ (No. 14) \\
\hline$a / \AA$ & $23.630(1)$ & $16.703(3)$ & $6.992(1)$ \\
\hline$b / \AA$ & $9.950(1)$ & $7.650(1)$ & $15.802(1)$ \\
\hline$c / \AA$ & $15.955(2)$ & $8.864(1)$ & $19.256(2)$ \\
\hline$\beta / \circ$ & $117.86(1)$ & $111.03(1)$ & $98.48(1)$ \\
\hline$U / \AA^{3}$ & $3316.5(6)$ & 1057.2(3) & $2104.3(4)$ \\
\hline$Z$ & 8 & 4 & 4 \\
\hline$D$ calc $/ \mathrm{Mg} \cdot \mathrm{m}^{-3}$ & 1.907 & 1.949 & 1.952 \\
\hline$\mu / \mathrm{mm}^{-1}$ & 0.214 & 0.213 & 0.214 \\
\hline No. collected & 3549 & 1185 & 4080 \\
\hline No. unique $\left[R_{\text {int }}\right]$ & $2920[0.0212]$ & $923[0.0373]$ & $2930[0.0180]$ \\
\hline No. parameters & 294 & 101 & 387 \\
\hline$R_{1}, w R_{2}[I>2 \sigma(I)]$ & $0.0407,0.0820$ & $0.0346,0.0875$ & $0.0346,0.0760$ \\
\hline$R_{1}, w R_{2}$ [all data] & $0.0777,0.0978$ & $0.0570,0.0986$ & $0.0537,0.0843$ \\
\hline Goodness of fit on $F^{2}$ & 1.012 & 1.048 & 1.015 \\
\hline
\end{tabular}


of-fit $=\left[\Sigma\left[w\left(F_{\mathrm{o}}{ }^{2}-F_{\mathrm{c}}{ }^{2}\right)^{2}\right] /(N-P)\right]^{1 / 2}$, where $N, P$ are the numbers of observations and parameters, respectively.

Supporting Information (see footnote on the first page of this article): CCDC No. 280475, 1,2,3,4,5,6,7,8-octafluorofluorene, 1; CCDC No. 280473, 1,2,3,4,5,6,7,8-octafluoro-9-(pentafluoro) phenylfluorene, 8; CCDC No. 280474, 1,1',2,2',3,3',4,4',5,5',6,6', 7,7',8,8'-hexadecafluoro-9,9'-bifluorenyl, 11, contains the supplementary crystallographic data for the X-ray studies reported in this paper. These data can be obtained free of charge at www.ccdc.cam.ac.uk/conts/retrieving.html [or from the Cambridge Crystallographic Data Centre, 12, Union Road, Cambridge CB2 1EZ, UK; fax: (internat.) +44-1223/336-033; E-mail: deposit@ccdc.cam.ac.uk].

\section{Acknowledgments}

The authors wish to thank the Ministero dell'Istruzione, dell'Università e della Ricerca (MIUR, Roma), Programma di Ricerca Scientifica di Notevole Interesse Nazionale 2004-5.

\section{References}

[1] (a) R. D. Chambers, M. Clark, D. J. Spring, J. Chem. Soc., Perkin I 1972, 2464-2469; (b) R. D. Chambers, M. Clark, J. Chem. Soc., Perkin I 1972, 2469-2474; (c) R. Filler, A. E. Fiebig, M. Y. Pelister, J. Org. Chem. 1980, 45, 1290-1295; (d) J. Mann, Chem. Soc. Rev. 1987, 16, 381-436; (e) R.G. Syvret, W.J. Casteel, G.S. Lal, J.S Goudar, J. Fluor. Chem. 2004, 125, 33-35.

[2] F. G. Bordwell, J. C. Branca, J. E. Bares, R. Filler, J. Org. Chem. 1988, 53, 780-782, and references therein.

[3] (a) J. N. Cooper, R. E. Powell, J. Am. Chem. Soc. 1963, 85, 15901592; (b) J. J. Eisch, R. J. Wilcsek, J. Organomet. Chem. 1974, 71, C21-C24; (c) J. L. R. Williams, J. C. Doty, P. J. Grisdale, R. Searle, T. H. Regan, G. P. Happ, D. P. Maier, J. Am. Chem. Soc. 1967, 89 5153-5157.

[4] (a) M. Brookhart, B. Grant, A. F. Volpe, jr., Organometallics 1992, 11, 3920-3922; (b) K. Fujiki, J. Ichikawa, H. Kobayashi, A. Sonoda, T. Sonoda, J. Fluorine Chem. 2000, 102, 293-300.

[5] (a) X. Yang, C. L. Stern, T. J. Marks, J. Am. Chem. Soc. 1994, 116 , 10015-10031; (b) L. Jia, X. Yang, A. Ishihara, T. J. Marks, Organometallics 1995, 14, 3135-3137; (c) L. Li, T.J. Marks, Organometallics 1998, 17, 3996-4003.

[6] (a) M. J. Amkung, T.L. Fletcher, J. Org. Chem. 1961, 26, $2243-$ 2244; (b) M. J. Namkung, T. L. Fletcher, Can. J. Chem. 1967, 45, 2569-2575; (c) T. L. Fletcher, W. H. Wetzel, M. J. Namkung, H.-L. Pan, J. Amer. Chem. Soc. 1959, 81, 1092-1094.

[7] (a) B. M. York, Jr. Int. Patent No. WO83/03543, Oct. 27, 1983 (to ALCON Laboratories, Inc.); (b) M. J. Namkung, T. L. Fletcher, W. H. Wetzel J. Med. Chem. 1965, 8, 551-554.

[8] G. M. Luthe, F. Ariese, U. A. D. Brinkman, Monofluorinated Polycyclic Aromatic Hydrocarbons: Standards in Environmental Chemistry and Biochemical Applications, in Handbook of Environmental Chemistry, A. H. Neilson, Ed., 2002, 3N, 249-275.

[9] (a) V. M. Vlasov, G. G. Yacobson, E.S. Petrov and A.I Shatenshtein, J. Fluorine Chem. 1977, 9, 321-325; (b) V.M. Vlasov, G. G. Yacobson, Zh. Org. Khim. 1978, 14, 2132-2137; Chem. Abs. 1979, 90, 86522q; (c) I. A. Koppel, R. W. Taft, F. Anvia, S.-Z. Zhu, L.-Q. Hu, K.-S. Sung, D. D. DesMarteau, L. M. Yagupolskii, Y. L. Yagupolskii, N. V. Ignat'ev, N. V. Kondratenko, A. Yu. Volkonskii, V. M. Vlasov, R. Notario, P.-C. Maria, J. Am. Chem. Soc. 1994, $116,3047-3057$

[10] (a) F. Calderazzo, F. Masi, G. Pampaloni, V. Passarelli, R. Santi, A. Sommazzi, S. Spera, F. Tumminia, J. Organomet. Chem. 2005, 690, 4886-4898; (b) A. Sommazzi, F. Masi, G. Borsotti, A. Proto, R Santi, European Patent No. EP1013675, Dec. 7, 1999 (to Enichem SpA), 1999; (c) A. Sommazzi, G. Borsotti, F. Masi, R. Santi, V. Bricco, Int. Patent WO02/50087, Jun. 27, 2002 (to Enichem SpA), 2002; (d) A. Sommazzi, F. Masi, G. Borsotti, R. Santi, F Calderazzo, G. Pampaloni, V. Passarelli, Int. Patent WO 03/010210, Feb. 6, 2003 (to Polimeri Europa SpA), 2003.

[11] H. Kessler, Angew. Chem., Internat. Ed. Engl. 1970, 9, 237-253.
[12] E. A. Chandross, C.F. Sheley, Jr., J. Am. Chem. Soc. 1968, 90, 43454354.

[13] Conquest version 1.10, Cambridge Crystallographic Data Centre, Cambridge, UK, 2007.

[14] Conquest version 1.10, Cambridge Crystallographic Data Centre, Cambridge, UK, 2007. Refcodes INOHOI, NAQTII, OLIZOY, POTQEU, RESSEN, UNOHAG.

[15] (a) D. A. Dougherty, F. M. Llort, K. Mislow, J. F. Blount, Tetrahedron 1978, 34, 1301-1306; (b) V. Shanmugham, W. K. Leong, Y. Zhu, Organometallics 2006, 25, 283-288.

[16] B.X. Solans, C. Miravitlles, J. P. Declercq, G. Germain, Acta Crystallogr., Sect. B: Struct. Sci. 1980, B36, 2677-2683.

[17] L. Jia, X. Yang, C. L. Stern, T. J. Marks, Organometallics 1997, 16 , 842-857.

[18] X. Yang, C. L. Stern, T. J. Marks, Angew. Chem., Int. Ed. Engl. 1992, 31, 1375-1377.

[19] M. Van Meerssche, G. Germain, J.-P. Declercq, D. Lloyd, D.J. Walton, Cryst. Struct. Commun. 1979, 8, 635-638.

[20] A. W. McLean, C. Y. Meyers, P. D. Robinson, Acta Crystallogr. Sect. E: Struct. Sci. 2004, 60, o75-076.

[21] J. Trotter, Structural chemistry of the $C-X$ bond, in The Chemistry of the Carbon-Halogen Bond, S. Patai, Ed., J. Wiley, London, 1973 , Part 1, pp. 49-62.

[22] R. D. Chambers, D. J. Spring, J. Chem. Soc. (C) 1968 2394-2397.

[23] S. C. Cohen, A. J. Tomlinson, M. R. Wiles, A. G. Massey, J. Organomet. Chem. 1968, 11, 385-392.

[24] C. T. North, C. Phillips, F. S. Mathews, Acta Crystallogr., Section A, Found. Crystallogr. 1968, 24, 351-358.

[25] G. M. Sheldrick, SHELXTL-Plus, Rel. 5.1, Bruker-AXS Corporation., Madison, Wisconsin, USA, 1997.

[26] L. J. Farrugia, J. Appl. Crystallogr. 1999, 32, 837-841. 
Figure 1

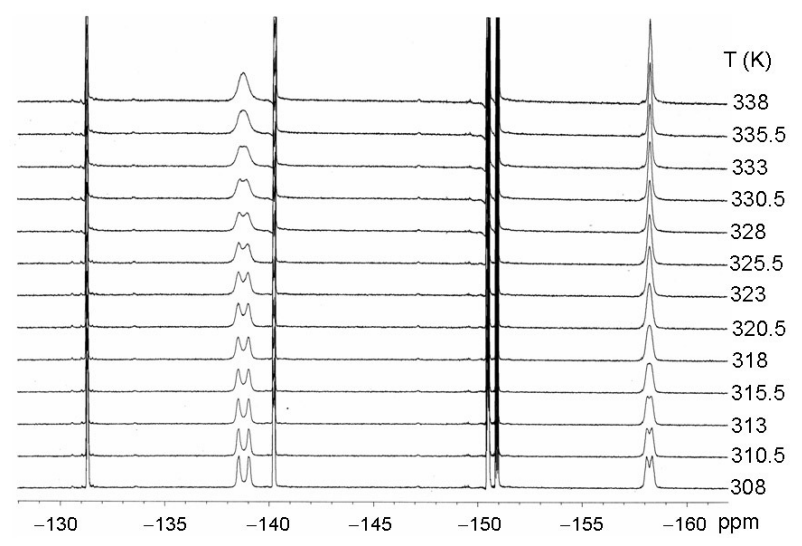

Figure 2
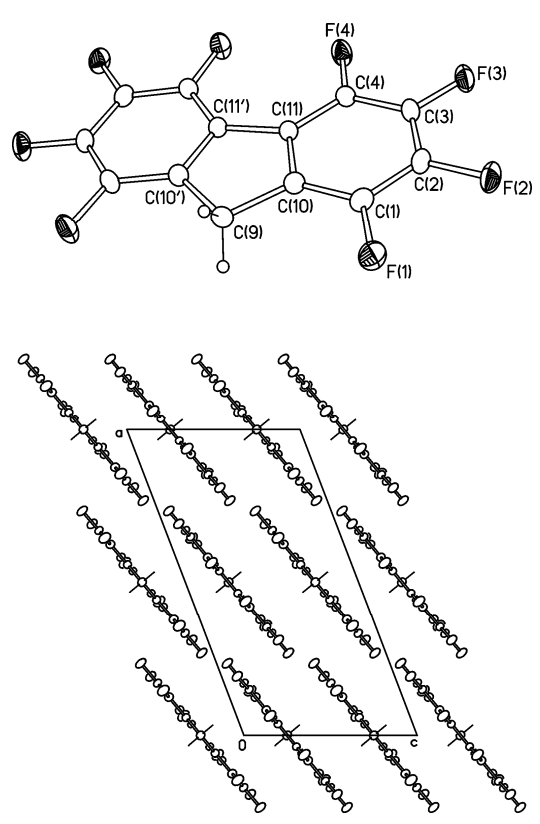
Figure 3

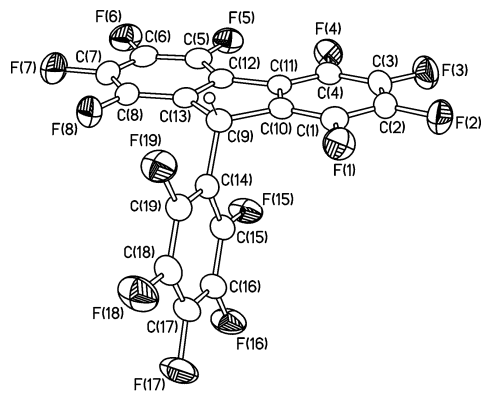

A

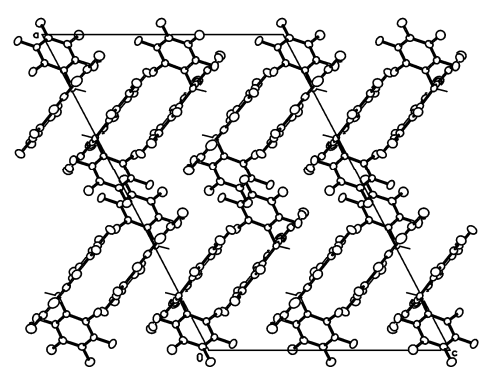

Figure 4
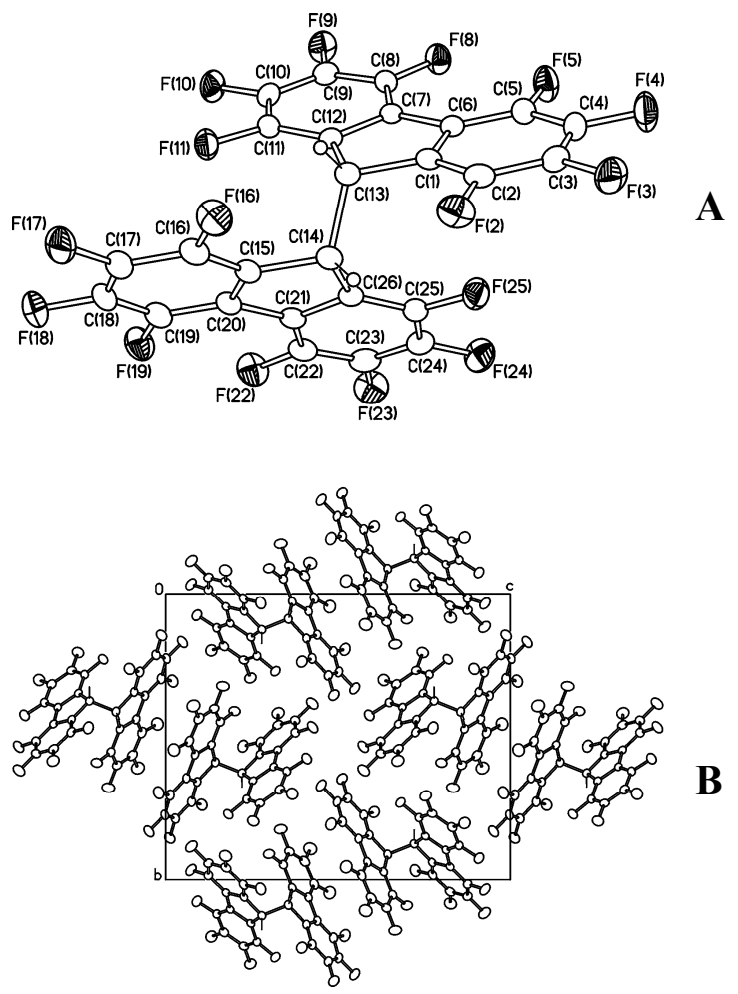
Fluorosubstituted Fluorenes

Several new octafluorofluorene derivatives have been prepared in high yields. The structures have been elucidated either in solution (variable temperature ${ }^{19} \mathrm{~F}-\mathrm{NMR}$ spectra) and/or in the solid state (X-ray crystal structures).
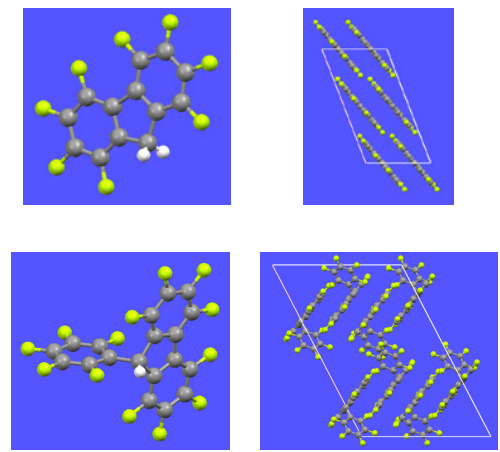

Fabio Marchetti, Fabio Marchetti, Francesco Masi, Guido Pampaloni, Vincenzo Passarelli, Anna Sommazzi, Silvia Spera

Synthesis, Variable Temperature NMR Investigations and Solid State

Characterization of Novel

Octafluorofluorene Compounds

Keywords: fluorine, fluoro derivatives, octafluorofluorene, crystal structures, NMR spectra 